\title{
O equilíbrio de antagonismos e o niger sum: relações raciais em Gilberto Freyre e Guerreiro Ramos
}

Layla Daniele Pedreira de Carvalho

Curso: Mestrado em Sociologia

Data da defesa: 4 de julho de 2008

Orientadora: Prof ${ }^{\mathrm{a}}$. Dra ${ }^{\mathrm{a}}$. Mariza Veloso Motta Santos

\section{Resumo}

As relações raciais constituem categoria essencial para a construção da idéia de brasilidade. Desde as primeiras discussões sobre o assunto, ainda no século XIX, os intelectuais brasileiros, informados pelas teorias "racialistas" européias, procuraram conciliar a construção da idéia de nação com a imensa massa de negros escravos e indígenas. Por todo o século XX, essa categoria pautou os trabalhos produzidos pelas ciências sociais e, durante os primeiros anos do século XXI, tem ocupado importante espaço nas discussões realizadas sobre a identidade da população brasileira.

Neste trabalho, tomamos dois momentos distintos do debate sobre as relações raciais no Brasil: primeiro, a leitura de Gilberto Freyre, produzida nos anos 1930, que enfatiza a mestiçagem como característica particular da sociedade formada pela colonização portuguesa, miscigenação que condiciona o equilíbrio de antagonismos entre os vários pólos das relações sociais estabelecidas na sociedade patriarcal brasileira: senhor e escravo, branco e negro, homem e mulher, casa-grande e senzala, sobrado e mocambo.

Depois, no final dos anos 1940, tomamos a leitura de Guerreiro Ramos e a sua abordagem do negro a partir da militância 
desse sociólogo no Teatro Experimental do Negro (TEN). O posicionamento de Ramos passa por uma leitura das relações raciais a partir da democracia racial e se dirige para a afirmação da negritude, por meio do niger sum, como forma de liberação da população negra da patologia social do branco brasileiro - a tentativa de negação da formação majoritariamente negra da população brasileira. As teorias defendidas por esses autores estão presentes no atual debate sobre as relações raciais em que, mais uma vez, se discutem as formas de inclusão dos grupos não-brancos na sociedade brasileira, enquanto, de um lado, se busca reafirmar o caráter miscigenado e cordial da população brasileira e, de outro, se nega essa cordialidade e se apontam os limites da miscigenação brasileira no que se refere à igualdade de direitos.

Palavras-chave: sociologia; pensamento social; relações raciais; Gilberto Freyre; equilíbrio de antagonismos; Guerreiro Ramos; niger sum. 